\title{
Comparative Home-Market Advantage: An Empirical Analysis of British and American Exports
}

\author{
Rolf Weder
}

University of Basel

\begin{abstract}
This paper derives and tests the hypothesis that a country exports relatively more of those goods for which it has a relatively larger home market, i.e., a comparative home-market advantage. This prediction is based on a two-country, many-good intraindustry trade model with economies of scale, international transaction costs and differences in expenditure shares and country size. The data from 1970 to 1987 of 26 industries of the manufacturing sector in the United States and the United Kingdom supports this hypothesis. It is also shown that the relationship between home-market size and export structure becomes significantly stronger for industries with high fixed costs. JEL no. F12, F14, F17
\end{abstract}

Keywords: International trade; home-market advantage; Ricardo; increasing returns to scale

\section{Introduction}

This paper has been motivated by two rather different strands in the trade literature. First, there exists a persistent hypothesis, triggered by the seminal contribution of Linder (1961), that countries export those products for which there is a large domestic demand. This "home-market effect" has achieved increasing attention in the trade literature during the last few years, in theoretical as well as empirical work. ${ }^{1}$ Second,

Remark: I am grateful to an anonymous referee, James Brander, David Green, Richard Harris, John Helliwell, Ronald Jones, Joris Pinkse, Nicolas Schmitt, and participants of seminars at the University of British Columbia, University of Geneva, University of St. Gallen, Simon Fraser University, and the WEA International Conference for helpful comments. Thanks to Peter Lloyd for making me aware of the data. Please address correspondence to Rolf Weder, Department of Economics (WWZ) and Europainstitut, University of Basel, Gellertstrasse 27, CH-4020 Basel, Switzerland; e-mail: rolf.weder@unibas.ch

1 Conceptual and theoretical contributions include Basevi (1970), Frenkel (1971), Hsu (1972), Krugman (1980), Feenstra (1982), Dinopoulos (1988), Davis (1995, 1998), Tri- 
there is a straightforward prediction of the pattern of trade made by the Ricardian theory of comparative advantage in the two-country, manygood case. It has been adopted in the pioneering empirical analysis by MacDougall (1951), followed up by others, focusing on the relationship between relative exports and labor costs of the United Kingdom (U.K.) and the United States (U.S.). ${ }^{2}$ The main idea of this paper is to contribute to the literature on home-market effects by deriving hypotheses from a demand-driven trade model with monopolistic competition and testing these hypotheses with British and American trade data. Thereby, some analogy to the Ricardian model and how it has been tested will be exploited.

It is well known that in a framework with constant returns to scale and diminishing returns to each factor of production, a country tends to import a good for which its demand is relatively large (Jones 1956). However, suppose that there exists some form of increasing returns to scale. In this case, a large domestic demand for a certain good tends to promote its export rather than its import. For example, firms may focus their R\&D efforts on those products for which there exists a large home demand (Linder 1961; Vernon 1966) which, in a dynamic process, may then create comparative advantage and thus lead to exports, as developed further in Bhagwati (1982), Feenstra (1982), and Dinopoulos (1988). The positive relationship also emerges in a static environment if firms face small international transaction costs of exports, as shown by Krugman (1980) in a model of monopolistic competition. Homemarket effects may also arise in models of oligopolistic competition as shown by, for example, Feenstra et al. (1998) as well as by Head et al. (2002), who compare different models.

This paper extends the Krugman (1980) approach to the two-country, many-good case and tests whether the predictions of the model fit the data. The general-equilibrium model assumes that there are two countries that only differ with respect to domestic expenditure shares and country size in a number of industries. Hypotheses are then derived

onfetti (2001a), Head et al. (2002). Recent empirical analyses focusing on this issue are Fagerberg (1995), Davis and Weinstein (1996, 1998, 1999), Weder (1996), Feenstra et al. (1998), Lundbäck and Torstensson (1998), Head and Ries (2001), Trionfetti (2001b), Brülhart and Trionfetti (2001, 2002a, 2002b).

2 Other analyses of the Ricardian model include Stern (1962) and Balassa (1963). Limitations of this approach are discussed in Bhagwati (1964), Deardorff (1984), and Leamer and Levinsohn (1995). 
which focus on the relationship between home-market size and the pattern of trade. First, the model predicts that countries tend to export relatively more of those products for which the domestic market is relatively large, i.e., where they have a "comparative home-market advantage." Second, the model suggests that high-economies-of-scale industries conform relatively better to this demand-export hypothesis than other industries. Thus, the degree of scale economies is an important determinant of the extent to which demand affects exports.

The empirical analysis of the relationship between home-market size and the pattern of trade for 26 industries of the U.S. and U.K. manufacturing sector over the period of 1970 to 1987 supports the model's main predictions. In particular, it is found that there is a positive relationship between relative exports and relative home-market size and that this relationship becomes significantly stronger for industries with high economies of scale. The latter result seems to be especially important. If an analysis does not (perfectly) control for differences in factor endowment and technologies between countries, an observed positive relationship between relative home-market size and exports may be in line with a traditional trade model where neither determines the other one. The findings that the positive relationship is stronger for high-economies-of-scale industries does, however, provide support for the demand-driven model considered in the paper.

The results relate to a number of recent empirical trade papers which consider home-market effects with the purpose of discriminating between the explanatory power of the traditional constant-returnsto-scale and the new increasing-returns-to-scale trade literature. The first empirical papers in this field by Hummels and Levinsohn (1995), Davis and Weinstein $(1996,1998)$, as well as Lundbäck and Torstensson (1998) showed mixed support for home-market effects and the increasing-returns-to-scale literature in explaining volume and pattern of trade and production. More recent studies by Feenstra et al. (1998), Davis and Weinstein (1999), Head and Ries (2001), Trionfetti (2001b) as well as Brülhart and Trionfetti (2002b) have found support for home-market effects, albeit in rather different settings and with the results needing to be qualified. These studies suggest that industry characteristics such as technology, entry and homogeneity of products are important for the existence and the size of home-market effects. An interesting approach is found in Brülhart and Trionfetti 
(2001, 2002a), who investigate the effects of home-biased public procurement on the pattern of specialization in the European Union. They also find empirical support of home-market effects for this "type of demand."3

To show how this paper differs from the literature described above, let me relate it to the two ideas that are probably most closely linked, i.e., Head and Ries (2001) and Brülhart and Trionfetti (2002b), both of which, however, are based on different models, empirical methods, trade data and countries. Whereas Head and Ries (2001) investigate whether home-market effects become stronger (weaker) - as predicted by the increasing-returns-to-scale (constant-returns-to-scale) industry - during a period of substantial trade liberalization between Canada and the U.S., this paper analyzes (among other things) whether the relationship is stronger in a group of high-economies-of-scale industries than in a group of low-economies-of-scale industries. The approach is also different from Brülhart and Trionfetti (2002b), who estimate home biases for a number of industries and countries and then implicitly discriminate between constant-returns-to-scale and increasing-returns-to-scale industries by using a gravity model and exploiting the expected relationship between inter-country differences in home biases and patterns of specialization. My paper does not intend to, and cannot, compare the predictive power of the traditional theory with that of the new trade theory, as it only focuses on one example (two countries, a number of manufacturing industries with a high share of intraindustry trade). One contribution of the paper is, however, that it tries to explicitly analyze whether home-market effects become stronger in industries which are characterized by larger fixed costs and thus a greater degree of economies of scale.

The remainder of the paper is organized as follows. Section 2 describes the model of comparative home-market advantage and the hypotheses following from it. The description of the data can be found in Section 3. The empirical analysis and the interpretation of the results are carried out in Section 4. Section 5 concludes.

\footnotetext{
3 Note also Fagerberg (1995), who investigates the international competitiveness of vertically related industries, as measured by an index of revealed comparative advantage (RCA). He finds some positive relationship between user and supplier industries' RCA for a number of industries and OECD countries which, again, can be interpreted as support for a demand-related explanation of the pattern of trade.
} 


\section{The Model and Its Hypotheses}

Imagine a world with two countries, home and foreign, that only differ with respect to their home-market size for different goods. In particular, it is assumed that consumers in the home and foreign country spend different shares of their income ( $s$ and $s^{*}$ ) on the available goods and that the two countries may also have a different population size $\left(L\right.$ and $\left.L^{*}\right){ }^{4}$ Each good is composed of many varieties which are produced at decreasing average costs. There is only one factor of production, labor, which is perfectly mobile within each country. Finally, there are small international transaction costs $(t>1)$ of the iceberg type, which can be interpreted so as to include any incremental variable costs associated with the supply of goods to the other market.

The relationship between home-market size and pattern of trade is discussed in Section 2.1 for the two-good case whose derivation can be found in Weder (1995) as an extension of Krugman (1980). In Section 2.2 , the model is expanded to the many-good case and comparative statics results are derived. Section 2.3 establishes the empirical hypotheses.

\subsection{Two-Good Case}

The representative consumer's preferences in the home (foreign) country are described by a Cobb-Douglas utility function, $U\left(U^{*}\right)$, with a constant share of income, $s_{i}\left(s_{i}^{*}\right)$, spent on goods 1 and 2 :

$$
\begin{aligned}
U & =C_{1}^{s_{1}} C_{2}^{s_{2}}, \\
U^{*} & =C_{1}^{* s_{1}^{*}} C_{2}^{* s_{2}^{*}}, \quad \text { where } s_{i}, s_{i}^{*}>0 ; s_{1}+s_{2}=1 ; s_{1}^{*}+s_{2}^{*}=1 .
\end{aligned}
$$

Each consumption aggregate $C_{i}\left(C_{i}^{*}\right)$ of home (foreign) consumers is composed of many varieties which enter symmetrically a CES subutility function, where $c_{i j}\left(c_{i j}^{*}\right)$ are the quantities of consumption of the $j$ th variety of good $i$, produced in the home (foreign) country:

$$
C_{i}, C_{i}^{*}=\sum_{j=1}^{n_{i}} c_{i j}^{\theta}+\sum_{j=1}^{n_{i}^{*}} c_{i j}^{* \theta}, \quad \text { where } 0<\theta<1 .
$$

\footnotetext{
4 For example, consumers in the U.K. may spend a larger share of their expenditures on small cars than the consumers in the U.S. However, given the larger number of consumers in the U.S., the home market for small cars is likely to be absolutely smaller in the U.K. than in the U.S.
} 
The endogenous number of varieties produced in the home (foreign) country is denoted by $n_{i}\left(n_{i}^{*}\right)$. The constant elasticity of substitution and price elasticity of demand is equal to $\sigma=1 /(1-\theta)$. The production of each variety is subject to decreasing average costs, which is represented by the cost function in terms of labor, $l_{i j}=a+b x_{i j}(a, b>0)$, with fixed costs, $a$, and constant marginal costs, $b$, where $l_{i j}$ describes the amount of labor used in the production of $x$ units of output of the $j$ th variety of the composite good $i$. The technology is identical in both countries and in all groups of goods.

In the open-economy equilibrium, home and foreign consumers maximize their utility by taking into account the different prices of home and foreign produced varieties of each good. Simultaneously, firms maximize profits in a setting of monopolistic competition by following the usual markup-pricing rule. Entry ensures that, in equilibrium, profits are driven down to zero. The profit-maximizing output $\left(x_{i j}\right)$ of all firms in both groups of goods and both countries is identical and independent of market size, which is due to the assumed utility function:

$$
x_{i j}=x_{i j}^{*}=\frac{a}{b}\left(\frac{\theta}{1-\theta}\right)=\frac{a}{b}(\sigma-1) .
$$

The relationship between the two countries' home-market size for the two groups of goods and the pattern of trade is established by deriving the general equilibrium, i.e., the relative number of varieties produced by the two countries in free trade. The following exogenous "home-market coefficients" can then be introduced which capture the home-market size of each group of products: $s_{1} L=M_{1}, s_{2} L=M_{2}, s_{1}^{*} L^{*}=M_{1}^{*}, s_{2}^{*} L^{*}=M_{2}^{*}$. If the foreign country has a much larger population than the home country, it is likely to have an absolutely larger home market in both groups of goods, i.e., $M_{1}^{*}>M_{1}$ and $M_{2}^{*}>M_{2}$.

It can be shown that, in spite of its absolute home-market disadvantage in both goods, the home country is a (net) exporter of that group of good where it has a relatively larger home market, i.e., where it has a comparative home-market advantage (Weder 1995: 351). ${ }^{5}$ Thus, the home country's balance of trade for good 1 is positive if and only if the

5 The notion "(net) exports" refers to the point that there may or may not exist twoway trade in a good. The lower transport costs and the bigger relative differences in home-market size are, the more likely a complete specialization is. 
following condition holds:

$$
\frac{M_{1}}{M_{2}}>\frac{M_{1}^{*}}{M_{2}^{*}} .
$$

The intuition is as follows. Suppose the two countries are identical in size $\left(L=L^{*}\right)$ - as assumed in Krugman (1980) - and that the home country's residents spend a larger portion of their income on good 1 $\left(s_{1}>s_{1}^{*}\right)$. In this case, the home country's firms producing group 1 varieties have a transaction cost advantage compared to their foreign competitors because of the absolutely larger home market in this group of products. Thus, relatively more firms in the home country enter group 1. Exports are boosted by an increase in the number of varieties of good $1 .^{6}$ The home country is a (net) exporter of good 1 and the foreign country a (net) exporter of good 2.

Now suppose the home country is much smaller than the foreign country. Thus, the foreign country is likely to have an absolutely larger home market in both groups of products. This implies that the foreign country faces a boost in its exports because of its absolute home-market advantage in both goods. However, this situation would lead to a trade surplus for the foreign country and a labor shortage in its labor market. The endogenous relative wage therefore compensates for the greater "competitiveness" of the foreign country's firms. The foreign country thus enjoys a higher wage rate in equilibrium $\left(w^{*}>w\right)$. This process establishes the analogy to the Ricardian trade model. Countries tend to be (net) exporters of that group of goods in which they have a comparative home-market advantage. Absolute advantages are reflected in the equilibrium wage rate. $^{7}$

\subsection{Many-Good Case and Comparative Statics}

Let me now establish the general equilibrium for the many-good case and derive some comparative statics. An increase in the number of composite goods from 2 to $G$ expands the utility function in (1) in a straightforward

\footnotetext{
6 We may denote this as a "magnification effect" as suggested by Trionfetti (2001b: 405 ) in this type of model.

7 Note that, like in the Ricardian model, absolute and comparative advantage is defined in terms of an exogenous variable (expenditure share times population) and does not include the wage rate.
} 
manner, where $s_{i}$ and $s_{i}^{*}$ are home and foreign consumers' expenditure shares of good $i$, respectively:

$$
\begin{aligned}
U & =\prod_{i=1}^{G} C_{i}^{s_{i}}, \quad \text { where } \sum_{i=1}^{G} s_{i}=\sum_{i=1}^{G} s_{i}^{*}=1 . \\
U^{*} & =\prod_{i=1}^{G} C_{i}^{* s_{i}^{*}},
\end{aligned}
$$

It can be shown that the relationship between comparative home-market advantage and pattern of trade, described in Section 2.1, also holds in the many-good case. First, the equilibrium relative wage rate, $w / w^{*}$, is determined by using the balanced trade condition and remains a positive function of the relative country size, $L / L^{*}$, and the parameters of the model (see A1-A3 in the Appendix):

$$
\frac{L}{L^{*}}=\frac{\left(w / w^{*}\right)^{\sigma}-t^{1-\sigma}}{\left(w / w^{*}\right)^{1-\sigma}-\left(w / w^{*}\right) t^{1-\sigma}} .
$$

Second, as wages adjust for the difference in country size according to (6), the home and foreign expenditure shares and thus relative home-market sizes remain decisive to explain the pattern of trade. By calculating exports of the home $\left(X_{i}\right)$ and foreign country $\left(X_{i}^{*}\right)$ in the open-economy equilibrium for good $i$, the following relationship between relative exports and relative home-market coefficients can be found (see A3-A5 in the Appendix):

$$
\begin{gathered}
\frac{X_{i}}{X_{i}^{*}}=\frac{\left(M_{i} / M_{i}^{*}\right)\left[1-q\left(w / w^{*}\right)\right]+\left[q q^{*}\left(w^{*} / w\right)-q\right]}{\left(L / L^{*}\right)\left[1-q^{*}\left(w^{*} / w\right)\right]+\left(M_{i} / M_{i}^{*}\right)\left[q q^{*}-q\left(w / w^{*}\right)\right]}, \\
\quad \text { where } q=\left(w / w^{*}\right)^{\sigma-1} t^{1-\sigma} \text { and } q^{*}=\left(w^{*} / w\right)^{\sigma-1} t^{1-\sigma} .
\end{gathered}
$$

Equations (6) and (7) determine the general equilibrium of the model. We are now interested in two questions - first, how relative exports depend on relative home-market size and, second, how this relationship is affected by a change in the degree of economies of scale. As the relationship depicted by (7) is quite complex, it will first be simulated and then be solved for one special case. The simulated example in Figure 1 assumes that international transaction costs are one-third of average costs $(t=1.5)$, the home country is five times as big as the foreign country $\left(L / L^{*}=5\right)$, and the relative wage is determined by $(6)$. 
Figure 1: Relative Exports and Relative Home-Market Sizes (simulation)

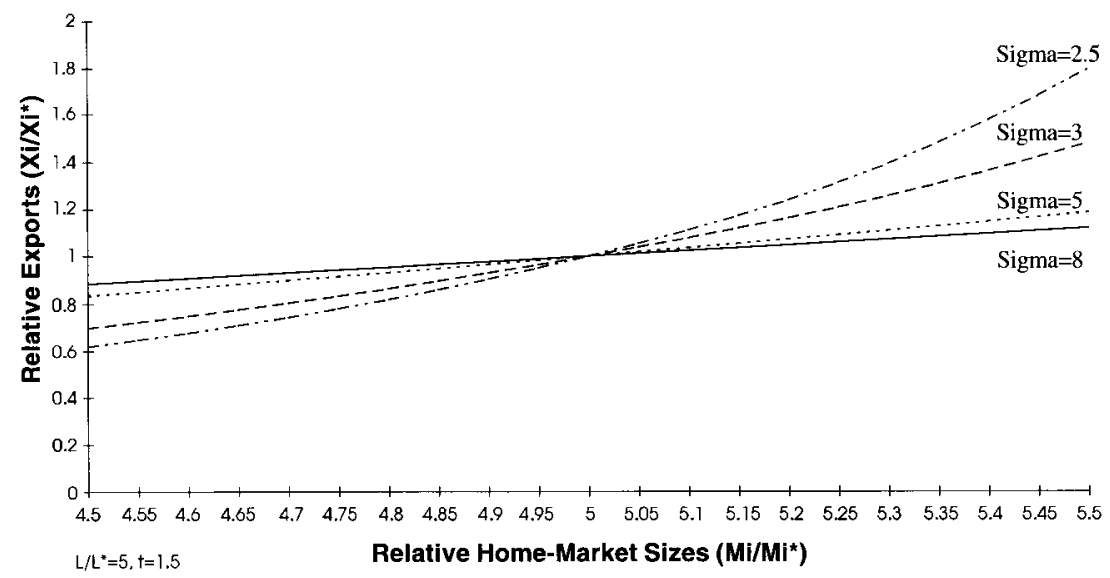

First, note from Figure 1 that there is a positive relationship between relative exports $\left(X_{i} / X_{i}^{*}\right)$ and relative home-market size $\left(M_{i} / M_{i}^{*}\right)$ for any given $\sigma$. This means that, for a given equilibrium wage rate, the home country's exports are relatively higher in those industries where domestic expenditure shares are relatively greater. The two countries' exports are identical in that industry where expenditure shares in the two countries happen to be identical, i.e., where the home country's home market is just five times as big as the foreign country's $\left(M_{i} / M_{i}^{*}=\right.$ $L / L^{*}=5$ ). This is possible because the home country's larger population size $\left(L>L^{*}\right)$ is reflected in a higher wage rate $\left(w>w^{*}\right)$, which makes sure that the relative home-market size determines the pattern of trade.

Figure 1 thus implies that, for given parameters $(\sigma, t)$, we can order and renumber all goods in a chain of decreasing relative home-market size. We calculate the ratio of the two countries' home-market size for each good $i$ and take into account that $M_{i} / M_{i}^{*}$ equals $L / L^{*}$ for that good of which the relative expenditure share $\left(s_{i} / s_{i}^{*}\right)$ happens to be equal to one. Thus,

$$
\frac{M_{1}}{M_{1}^{*}}>\frac{M_{2}}{M_{2}^{*}}>\cdots>\frac{L}{L^{*}}>\cdots>\frac{M_{i}}{M_{i}^{*}}>\cdots>\frac{M_{G}}{M_{G}^{*}} .
$$

The home country tends to export relatively more of those goods with a low index, the foreign country relatively more of those with a high 
index. The relative country size $\left(L / L^{*}\right)$ determines where this "chain of comparative home-market advantage" is broken and, thus, of which goods the home country exports relatively more than the foreign country. ${ }^{8}$ There may exist complete specialization with respect to some goods (more likely for those at the two ends of the chain), whereas other goods may be produced by both countries.

Second, Figure 1 reveals that the positive relationship between relative exports $\left(X_{i} / X_{i}^{*}\right)$ and relative home-market size $\left(M_{i} / M_{i}^{*}\right)$ becomes stronger for smaller values of $\sigma$ as indicated by the steeper dotted lines. A smaller elasticity of substitution implies a higher mark-up per firm, which positively affects producer prices and the relative cost advantage of firms with a larger home market. This tends to increase home-market effects. Note that in the model a change in $\sigma$ affects relative exports not only directly through (7), but also indirectly through a change in the relative wage rate in (6). The total effect is captured by Figure 1 for different values of $\sigma .^{9}$

In interpreting this result, it is important to note Krugman's (1980: 957) description of $\sigma$ as an inverse "index of the importance of scale economies." The point is that a lower elasticity of substitution causes a lower output per firm in equilibrium, as can be seen from (3). As fixed costs are spread over fewer units, average costs become much higher than marginal costs. The ratio of total variable costs, $b x_{i j}$, over fixed costs, $a$, thus decreases with smaller $\sigma$ in (3). A lower $\sigma$ can therefore be interpreted as a situation that is consistent with relatively high fixed costs and, therefore, a greater degree of economies of scale in equilibrium.

As emphasized by a referee, a change in fixed costs, $a$, does not affect the magnitude of home-market effects in this particular model because of the constant elasticity of substitution. An increase in fixed costs would simply shift out the average cost curve and make firms produce a larger quantity at the same price as before (equation (3)). In other more complex models, however, an increase in fixed costs may influence the elasticity of substitution, and thus prices, which in turn would magnify home-market effects. For example, in a monopolistic competition model with linear demand and a continuum of goods - the

8 Equation (8) demonstrates the analogy to the Ricardian model with its "chain of decreasing relative labor costs;" see, e.g., Jones and Neary (1984: 12).

9 These are reasonable values of $\sigma$ (see, e.g., Mercenier and Schmitt 1996). 
one introduced by Ottaviano et al. (2002) -, a change in fixed costs would increase home-market effects, as also shown by Head et al. (2002). ${ }^{10}$

Note that the two results discussed above can be derived as an explicit solution of (7) for the special case where countries are equal in size $\left(L=L^{*}\right)$. In this case, wages are identical $\left(w=w^{*}\right)$ in equilibrium as shown by (6), which greatly simplifies (7) to

$$
\frac{X_{i}}{X_{i}^{*}}=\frac{\left(M_{i} / M_{i}^{*}\right)-t^{1-\sigma}}{1-\left(M_{i} / M_{i}^{*}\right) t^{1-\sigma}} .
$$

Differentiation of (9) with respect to relative home-market size, $M_{i} / M_{i}^{*}$, yields

$$
\frac{\partial\left(X_{i} / X_{i}^{*}\right)}{\partial\left(M_{i} / M_{i}^{*}\right)}=\frac{1-t^{2-2 \sigma}}{\left[1-\left(M_{i} / M_{i}^{*}\right) t^{1-\sigma}\right]^{2}}>0,
$$

since $t$ and $\sigma$ are greater than 1 . This confirms that relative exports are increasing in relative home-market size. Differentiation of (9) with respect to the index of economies of scale, $\sigma$, yields

$$
\frac{\partial\left(X_{i} / X_{i}^{*}\right)}{\partial \sigma}=\frac{t^{1-\sigma} \ln (t)\left[1-\left(M_{i} / M_{i}^{*}\right)^{2}\right]}{\left[1-\left(M_{i} / M_{i}^{*}\right) t^{1-\sigma}\right]^{2}} .
$$

This first derivative is negative (positive) if $M_{i} / M_{i}^{*}$ is greater (smaller) than 1 and it is equal to zero if $M_{i} / M_{i}^{*}$ is equal to one. This means that relative exports of the home country increase with a greater degree of economies of scale (i.e., smaller $\sigma$ ) in those industries where the home country's market is larger than abroad. Relative exports decrease for domestic industries with a smaller home market and they do not change for industries for which the home and foreign country's home market is identical. These results are in line with the simulation in Figure 1. The difference is that, in this special case, the functional relationship between relative exports and home-market size goes through and pivots at the point where $X_{i} / X_{i}^{*}=1$ and $M_{i} / M_{i}^{*}=s_{i} / s_{i}^{*}=1$.

\subsection{Empirical Hypotheses}

The model and its comparative statics thus imply two hypotheses for the two-country, many-good case: (1) a country exports relatively more of

${ }_{10}$ Another approach would be Krugman (1979) with an endogenous elasticity of substitution. 
those goods for which its home market is relatively larger, (2) the positive relationship between relative home-market size and relative exports becomes stronger if production is characterized by large scale economies.

As the paper has been motivated by the Ricardian model and its empirical analyses, the investigation of these two hypotheses will be based on exports of the U.S. and the U.K. to third countries for a number of industries, $i$. Thereby, a linear relationship between relative exports $\left(E_{i}^{U . S .} / E_{i}^{U . K .}\right)$ and relative home-market size $\left(M_{i}^{U . S .} / M_{i}^{U . K .}\right)$ is assumed which can simply be estimated by the ordinary least squares estimator (OLS):

$$
\frac{E_{i}^{U . S .}}{E_{i}^{U . K .}}=\beta_{0}+\beta_{1} \frac{M_{i}^{U . S .}}{M_{i}^{\text {U.K. }}}+\varepsilon_{i} .
$$

Note that the model predicts a positive slope coefficient as U.S. exports are expected to be relatively higher in those industries where the U.S. home market is relatively larger. Also recall that, in the model, $M_{i}$ has been defined as the country size $(L)$ multiplied by the expenditure share $\left(s_{i}\right)$. Thus, $M_{i}$ reflects the real absolute home-market size, which could be interpreted as the number of "people equivalents" who buy good $i .{ }^{11}$ This variable will not be available in the data. If, however, we multiply $M_{i}$ by the equilibrium wage rate, $w$, we arrive at a monetary variable of market size $\left(L s_{i} w\right)$, which reflects the income or total expenditures of the economy spent on good $i$. Alternatively, we could reduce $M_{i}$ to the expenditure share of good $i, s_{i}$, by dividing $M_{i}$ through the population size, $L$, as discussed when establishing (4). In the empirical part, we will apply the first option, because it keeps the possible distinction between absolute and comparative home-market advantage introduced in Sections 2.1. and 2.2. ${ }^{12}$ Also note the three following considerations when stepping from the theoretical model to its empirical analysis.

11 Note that, in the model, each consumer buys a little bit of all varieties of each good.

${ }_{12}$ The difference between defining $M_{i}$ in terms of expenditure share $\left(s_{i}\right)$ or in terms of the value of home-market size $\left(L_{i} w\right)$ is basically that the explanatory variable is multiplied by a constant for all industries (e.g., by the relative equilibrium wage rate, $w^{U . S .} / w^{U . K}$, in order to obtain the value of relative home-market size). As long as we do a cross-section analysis at a certain point in time with a given relative wage rate, the quality of the results will be the same for both cases. If different periods (panel data) with, for example, a changing relative wage rate over time are included, the results of the two options could, in principle, differ. We will come back to this point in the empirical part. 
First, it is assumed that there is a linear relationship between relative exports and relative home-market size. As can be seen from (7), the model does not predict this linearity, in general. Note, however, that it is not the model with its precise functional form which will be analyzed below. The main interest of the empirical analysis belongs to the model's comparative statics as simulated in Figure 1 and explicitly derived in (10) and (11) for a special case. To which extent relative exports increase with rising relative home-market size, i.e., the sign of the second derivative, will highly depend on the precise specification of the model. The important prediction to be tested is that the relationship is positive and that it becomes steeper with a greater degree of economies of scale.

Second, the model is about trade in final goods - which is the case for a large body of international trade theory - whereas the data includes trade of products at various stages of production. Note, however, that the model could be thought of as to describe a relationship between exports and home-market size of intermediate products by interpreting the utility and subutility functions as production functions where an endogenously determined number of intermediate products enters the production of final goods (see Ethier 1982: 391).

Third, the empirical analysis concentrates on relative exports of the two countries to third markets. The reasons are analogous to the ones brought forward in the empirical analyses of the Ricardian trade model. ${ }^{13}$ Taking bilateral trade flows would bring the disadvantage that these flows are typically much smaller and more volatile than third-country exports and that they are usually distorted by asymmetric trade protection by the two investigated countries. ${ }^{14}$ Also note that, similarly to the Ricardian model, our "home-market model" is principally in line with such an empirical investigation, because relative cost advantages created by differences in the home-market size will also carry over to the two countries' competitive position in third markets. Thus, we compare the relative export performance of the two countries in a number of industries in third

\footnotetext{
13 See MacDougall (1951), Stern (1962) and Balassa (1963), who all focus their analyses of the Ricardian model on exports to third countries despite the fact that the Ricardian model is discussed in a two-country setting. Deardorff (1984: 477) supports this approach even though it has been criticized by Bhagwati (1964).

14 Note that in a multilateral trade system a third-country's import barrier is likely to affect the two countries' exports symmetrically (most-favored-nation principle), whereas each of the two countries' trade barriers might very well differ and thus distort bilateral trade flows.
} 
markets and investigate whether this performance is positively related to the exporting countries' relative home-market size. The relative thirdmarket access for different industries is, therefore, assumed to be equal for both exporting countries.

\section{Data Description}

The empirical analysis focuses on the complete ISIC groups 38 (manufactures of fabricated metal products, machinery and equipment) and 39 (other manufacturing industries) of the manufacturing sector. ${ }^{15}$ They include 26 industries on the 4-digit ISIC level, representing 60 percent of total U.S. and 50 percent of British exports of manufactured goods (see Table 1). These two groups seem to be in line with the model's main assumptions, as the industries are not resource-based and, at the same time, are characterized by a high share of intraindustry trade as measured by the Grubel-Lloyd index. ${ }^{16}$ The figures are from the International Economic Data Bank (IEDB) and include yearly data for the period 1970-1987 in U.S. dollars. ${ }^{17}$

Note that the figures in Table 1 are yearly averages of the two countries' third-market exports $\left(E_{i}\right)$ and home-market sizes $\left(M_{i}\right)$. Homemarket sizes are calculated by taking production plus imports minus exports per industry. This so-called "apparent consumption" corresponds to actual domestic consumption and thus home-market size per industry if there are no changes in inventories. This suggests to focus the analysis on long periods in order to eliminate changes in inventories. The figures shown in Table 1 are one example of long-term averages

15 Note that two industries within class 38 have been eliminated because of obvious data errors: ISIC 3801 (negative consumption over the whole period of investigation) and ISIC 3849 (not reported by the U.S. after 1987 and showing a huge and unusual deviation from OECD trade data (OECD 1993) by a factor of 25 to 90 ).

16 Other ISIC groups include many industries whose production is heavily dependent on resource endowments (e.g., dairy products in group 31, basic industrial chemicals in group 35 or iron and steel basic industries in group 37). This is confirmed by the Grubel-Lloyd index of intraindustry trade (Grubel and Lloyd 1975), which turns out to be highest for 38 and 39 in both countries relative to all other ISIC groups.

17 IEDB is at the Australian National University (Canberra). The number of 4-digit industries is larger than the one provided by the OECD in its "Industrial Structure Statistics," and third-country exports can be derived. Trade and production data are matched on a 4-digit ISIC level based on UN COMTRADE (trade) and OECD COMTAP (production) data. 
Table 1: U.S. and U.K. Exports to Third Countries and Home-Market Size, 1970-1987 (yearly average; 1.000 U.S. dollars)

\begin{tabular}{|c|c|c|c|c|}
\hline \multirow[b]{2}{*}{ Industries (ISIC 38 and 39) } & \multicolumn{2}{|c|}{ Exports } & \multicolumn{2}{|c|}{ Home market } \\
\hline & U.S. & U.K. & U.S. & U.K. \\
\hline 3811-CUTLERY, HAND TOOLS & 927,481 & 365,199 & $9,956,154$ & 800,666 \\
\hline 3812-FURNITURES, FIXTURES & 113,286 & 51,721 & $6,364,778$ & 627,638 \\
\hline 3813-STRUCTURAL METAL PRODUCTS & $1,467,105$ & 922,842 & $22,838,990$ & $4,119,450$ \\
\hline 3819-FABR MET PRD EXC MACH EQP NEC & $1,649,474$ & $1,181,604$ & $53,661,566$ & $8,471,248$ \\
\hline 3821-ENGINES, TURBINES & 412,878 & 206,196 & $4,660,475$ & 834,683 \\
\hline 3822-AGRIC MACHINERY AND EQUIP & 936,043 & 357,395 & $10,804,754$ & $1,893,177$ \\
\hline 3823-METAL \& WOODWORKING EQUIP & $1,270,926$ & 586,671 & $16,112,689$ & $1,248,276$ \\
\hline 3824-SPEC IND MACH \& EQP EX 3823 & $6,170,871$ & $2,753,173$ & $22,203,140$ & $4,276,552$ \\
\hline 3825-OFF,COMPUTG,ACCOUNTG MACH & $6,302,517$ & $1,971,466$ & $24,365,495$ & $3,040,063$ \\
\hline 3829-MACH,EQUIP EX ELECT NEC & $6,487,846$ & $2,717,159$ & $56,157,942$ & $10,060,403$ \\
\hline 3831-ELEC IND MACH \& APPARATUS & 998,256 & 475,092 & $22,306,461$ & $3,736,831$ \\
\hline 3832-RADIO, TELE, COMM EQP, APPAR & $7,969,005$ & $2,584,673$ & $66,887,063$ & $8,585,906$ \\
\hline 3833-ELEC APPLNCS \& HOUSEWARES & 146,014 & 95,168 & $4,146,195$ & $1,028,046$ \\
\hline 3839-ELEC APPAR \& SUPPLIES NEC & $1,350,795$ & 733,823 & $18,799,187$ & $3,271,421$ \\
\hline 3841-SHIPBUILDING \& REPAIRING & $1,221,357$ & 760,781 & $11,377,280$ & $1,547,750$ \\
\hline 3842-RAILROAD EQUIPMENT & 414,094 & 118,003 & $3,548,156$ & 307,701 \\
\hline 3843-MOTOR VEHICLES & $13,327,179$ & $4,309,322$ & $141,303,053$ & $14,054,101$ \\
\hline 3844-MOTOR CYCLES \& BICYCLES & 81,327 & 93,103 & $2,229,602$ & 316,603 \\
\hline 3845-AIRCRAFT & $9,747,007$ & $2,556,737$ & $33,267,196$ & $2,619,614$ \\
\hline 3851-PROF, SCIEN, MSRG, CNTRL EQU & $3,733,034$ & $1,481,025$ & $16,691,501$ & $2,675,848$ \\
\hline 3852-PROF, SC, MSRG, CONT EQU NEC & $1,101,005$ & 531,013 & $9,812,964$ & 787,260 \\
\hline 3853-WATCHES \& CLOCKS & 68,394 & 61,748 & $1,988,996$ & 461,226 \\
\hline 3901-JEWELRY \& RELATED ARTICLES & 447,391 & $1,374,672$ & $4,647,076$ & 782,304 \\
\hline 3902-MUSICAL INSTRUMENTS & 102,639 & 35,053 & 924,115 & 127,134 \\
\hline 3903-SPORTING \& ATHLETIC GOODS & 63,007 & 22,523 & $2,946,172$ & 287,498 \\
\hline 3909-MANUF INDUSTRIES NEC & 332,482 & 263,608 & $11,567,355$ & $2,040,870$ \\
\hline Percent of Total Manufacturing ( 3000 ) & $60 \%$ & $50 \%$ & & \\
\hline
\end{tabular}

Source: Based on data from IEDB (Australian National University).

(18-year averages). Shorter time periods will also be considered in the empirical analyses. Also note that these figures include intermediate and final products as mentioned above.

\section{Empirical Analysis}

The relationship between the ratio of U.S. to U.K. home-market size and the ratio of U.S. to U.K. exports to third countries is illustrated by Figure 2 for the 26 industries described in Table 1 . Note that Figure 2 is based on the longest period, i.e., 1970-1987 averages of exports and homemarket size. The picture suggests that there exists a positive relationship between relative exports and relative home-market size. Thus, the larger 
the U.S. relative to the U.K. home market, the larger U.S. relative to U.K. third-country exports are. Also note that the home-market size is absolutely larger in the U.S. for all industries (the ratio starts at 4) because of the much larger country size of the United States. Exports of the U.S., however, are generally not as much larger and even smaller for a few industries. This, again, is in line with the model which proposes that comparative and not absolute home-market advantages determine the pattern of trade. So, in a rough way at least, Figure 2 provides some

Figure 2: Relative Exports and Home-Market Sizes of the U.S. and the U.K. (average of 1970-1987)

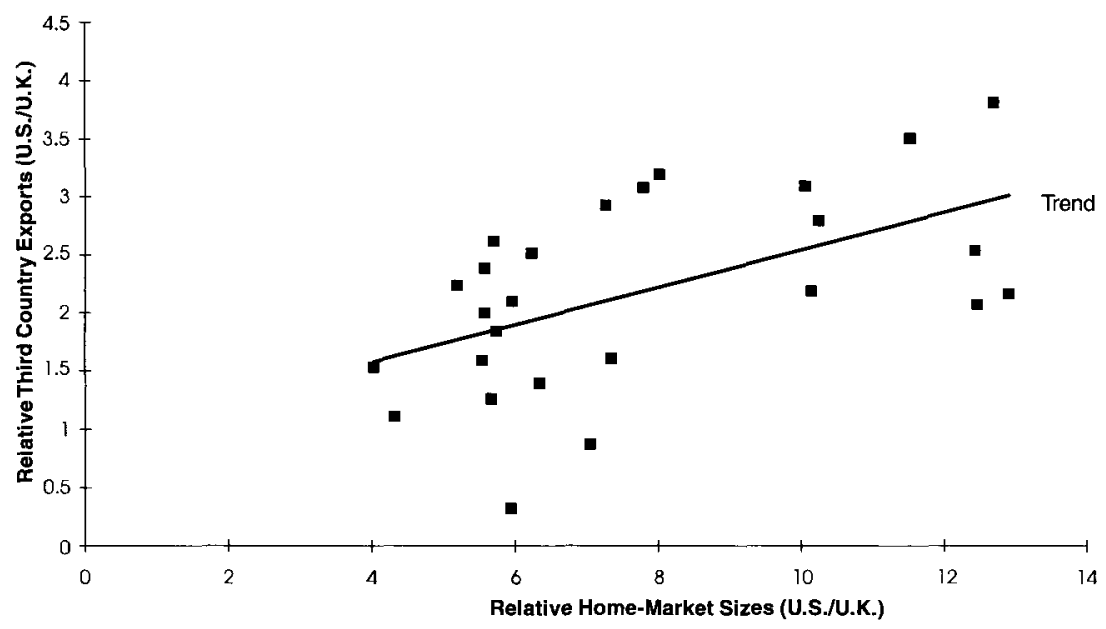

support of the positive relationship between relative home-market size and relative exports. This first hypothesis will be tested more carefully in Section 4.1, whereas Section 4.2 is devoted to the second hypothesis regarding the different behavior of high- and low-economies-of-scale industries.

\subsection{Exports and Home-Market Size}

The estimation of the first hypothesis by OLS confirms the picture given by Figure 2. Taking averages of relative exports and relative home-market sizes over the whole time period (1970-1987), the regression provides 
the following result:

$$
\frac{E^{U . S .}}{E^{U . K .}}=\underset{(0.42)}{0.93^{*}}+\underset{(0.05)}{0.16^{* *}} \frac{M^{U . S .}}{M^{U . K .}}, \quad\left(\overline{\mathrm{R}}^{2}=0.26\right) .
$$

The coefficient, $\beta_{1}=0.16$, has the expected sign and is significant at the 1 percent level with a $t$-value of 3.16 . Thus, the null hypothesis, $\beta_{1} \leq 0$, is rejected. This result supports the prediction of the model. In order to investigate whether this relationship is relatively constant and to exploit the full information available from the data set, a number of regressions have been performed for different subperiods and pooled data. Table 2 reports the results.

For the nonpooled estimations, it is found that the slope coefficient has the expected positive sign in all subperiods, i.e., in the different 9-, 6-, and 3-year averages. The null hypothesis that the coefficient is equal to or smaller than zero is rejected in all cases ( 8 times on the 1 percent and 4 times on the 5 percent significance level).$^{18}$ In order to get better estimates of the coefficients, one may want to exploit the full information from the data set by pooling the different periods, i.e., each of the 9-, 6-, 3-, and 1-year averages. OLS estimations reveal that the slope coefficient is positive and highly significant in all regressions (see the lower part of Table 2). ${ }^{19}$ An examination of first-order autocorrelation between an industry's residuals over time shows, however, that the estimated autocorrelation coefficients $(\rho)$ are significantly different from zero implying that the $t$-values may be overestimated.

This is taken into account by the generalized least squares estimator (GLS), i.e., the application of OLS to the data transformed by a "quasifirst-difference transformation" [GLS (Auto)]. ${ }^{20}$ In addition, Table 2

18 As ratios are taken for the dependent and independent variable, we would not expect error terms to be correlated between industries. A Goldfeld-Quandt test as well as the calculation of the White estimator showed no evidence of heteroskedasticity.

19 If we replace absolute home-market sizes $\left(M_{i}\right)$ by the expenditures shares $\left(s_{i}\right)$, the results remain qualitatively unchanged. All coefficients in the pooled regressions are significantly different from zero. We thus limit the further empirical analysis to $M_{i}$ as proposed and discussed in the theoretical part.

20 Assume relative exports of industry $i$ and time period $t$ are denoted by $E_{t}$. The "quasi-first-order transformation" implies that for all time periods except the first one we calculate new values of $E\left(E_{t}^{\prime}\right)$ where $E_{t}^{\prime}=E_{t}-\rho E_{t-1}$. For the first period, $E_{1}^{\prime}=$ $\left(1-\rho^{2}\right)^{1 / 2} E_{1}$ is applied in order to keep as many observations as possible (PraisWinston transformation). This standard procedure is also applied to the independent variable (relative home-market size). 
Weder: Comparative Home-Market Advantage

Table 2: Results of OLS/GLS-Estimations for 26 Industries, Different Periods and Pooled Data

\begin{tabular}{|c|c|c|c|c|}
\hline Estimation periods & $\begin{array}{l}\text { Slope } \\
\text { coefficient } \\
\quad\left(\beta_{1}\right)\end{array}$ & $\mathrm{t}$-value of $\beta_{1}$ & $\begin{array}{c}\mathrm{R}^{2} \\
\text { (adj.) }\end{array}$ & $\begin{array}{l}\text { No. of } \\
\text { obser- } \\
\text { vations }\end{array}$ \\
\hline & \multicolumn{4}{|c|}{ Non-pooled estimations (OLS) } \\
\hline $70-87$ & $0.16^{* *}$ & 3.16 & 0.26 & 26 \\
\hline $70-78$ & $0.26^{* *}$ & 4.01 & 0.38 & 26 \\
\hline $79-87$ & $0.13^{* *}$ & 2.66 & 0.20 & 26 \\
\hline $70-75$ & $0.28^{* *}$ & 4.30 & 0.41 & 26 \\
\hline $76-81$ & $0.14^{* *}$ & 2.50 & 0.17 & 26 \\
\hline $82-87$ & $0.12^{\star}$ & 2.47 & 0.17 & 26 \\
\hline $70-72$ & $0.20^{* *}$ & 3.18 & 0.27 & 26 \\
\hline $73-75$ & $0.34^{* *}$ & 5.01 & 0.49 & 26 \\
\hline $76-78$ & $0.21^{\text {** }}$ & 3.36 & 0.29 & 26 \\
\hline $79-81$ & $0.11^{*}$ & 1.88 & 0.09 & 26 \\
\hline $82-84$ & $0.13^{*}$ & 2.43 & 0.16 & 26 \\
\hline \multirow[t]{2}{*}{$85-87$} & $0.12^{\star}$ & 2.16 & 0.14 & 26 \\
\hline & \multicolumn{4}{|c|}{ Pooled estimations (OLS/GLS) } \\
\hline 9-year averages & $\rho=0.47$ & & 030 & 5 \\
\hline $\begin{array}{l}\text { - OLS } \\
\text { - GLS (Auto) }\end{array}$ & $\begin{array}{l}0.20^{* *} \\
0.24^{* *}\end{array}$ & $\begin{array}{l}4.82 \\
5.59\end{array}$ & $\begin{array}{l}0.30 \\
0.37\end{array}$ & $\begin{array}{l}52 \\
52\end{array}$ \\
\hline - GLS (Auto, Het) & $0.24^{* *}$ & 3.77 & 0.37 & 52 \\
\hline 6-year averages & \multicolumn{4}{|l|}{$\rho=0.54$} \\
\hline - OLS & $0.19^{* *}$ & 5.68 & 0.29 & 78 \\
\hline - GLS (Auto) & $0.22^{* *}$ & 6.52 & 0.35 & 78 \\
\hline - GLS (Auto, Het) & $0.22^{* *}$ & 3.63 & 0.35 & 78 \\
\hline 3-year averages & \multicolumn{4}{|l|}{$\rho=0.72$} \\
\hline - OLS & $0.19^{\star *}$ & 7.68 & 0.27 & 156 \\
\hline - GLS (Auto) & $0.18^{\star *}$ & 7.09 & 0.24 & 156 \\
\hline - GLS (Auto, Het) & $0.18^{* *}$ & 5.05 & 0.24 & 156 \\
\hline 1-year averages & \multicolumn{4}{|l|}{$\rho=0.85$} \\
\hline- OLS & $0.18^{* *}$ & 12.81 & 0.26 & 468 \\
\hline - GLS (Auto) & $0.15^{\star *}$ & 9.91 & 0.17 & 468 \\
\hline - GLS (Auto, Het) & $0.15^{\star *}$ & 6.26 & 0.17 & 468 \\
\hline \multicolumn{5}{|c|}{$\begin{array}{l}\text { significant at the } 1 \text { percent level. }-* \text { significant at the } 5 \text { percent level. - GLS (Auto) } \\
=\text { OLS in transformed data, corrected for first-order autocorrelation. - GLS (Auto, Het) } \\
=\text { OLS in transformed data, corrected for first-order autocorrelation and applying the } \\
\text { White estimator for an unknown form of heteroskedasticity. }\end{array}$} \\
\hline
\end{tabular}


also reports the White estimator on the transformed data [GLS (Auto, Het)], which corrects for an unknown form of heteroskedasticity. Table 2 shows that the slope coefficient remains significantly different from and greater than zero in all corrected pooled regressions on the 1 percent significance level. ${ }^{21}$ Thus, we conclude that there is a highly significant positive relationship between relative exports and relative home-market size for the nonpooled and pooled regressions.

RESULT 1: There is strong support of the first hypothesis that exports are relatively higher in those industries where the home market is relatively larger.

\subsection{Scale Economies}

The question is whether greater increasing returns do cause greater home-market effects, as suggested by the model. The analysis of this second hypothesis requires to select industries with high economies of scale and to test whether the slope coefficient of the high-economies-of-scale industries is significantly greater than the one of the other industries. Given the restrictions from the data which has to provide any information for the same industry classification used in the trade and production data, I use higher average firm size as a proxy for greater fixed costs and thus larger economies of scale among the 26 industries. Based on the available data, the ratio of (i) employment per firm, (ii) salaries and wages per firm and (iii) value added per firm for each industry and country have been calculated for 1987 or 1988 and for $1992 .{ }^{22}$ Table 3 provides the corresponding indices.

For example, the three indices of concentration in industry 3813 (structural metal products) and 3853 (watches and clocks) are considerably below the two countries' average index (which is equal to 100) in both years, whereas the indices for industry 3845 (aircraft) are highest among all industries. These are plausible figures as fixed costs are usually considered to be low in the watch industry and high in the aircraft indus-

21 This result does not change if the analysis allows for different autocorrelation coefficients $(\rho)$ for each industry (SURE analysis).

22 See Loertscher and Wolter (1980: 284) who also take value added per firm as an indicator of increasing returns to scale. Harris (1984: 1021) argues that low-fixedcost industries have small maximum economies of scale and a large number of firms. A discussion of different measures of economies of scale is found in Harrigan (1994). 
Table 3: Indices of Industry Concentration as an Approximation for Differences in Economies of Scale among Industries (average $=100$ )

\begin{tabular}{|c|c|c|c|c|c|c|c|c|c|c|c|c|c|}
\hline \multirow[t]{2}{*}{ ISIC } & \multicolumn{4}{|c|}{$\begin{array}{l}\text { Employment per } \\
\text { establishment }\end{array}$} & \multicolumn{4}{|c|}{$\begin{array}{c}\text { Salaries and wages per } \\
\text { establishment }\end{array}$} & \multicolumn{4}{|c|}{$\begin{array}{l}\text { Value added per } \\
\text { establishment }\end{array}$} & \multirow[t]{2}{*}{$\begin{array}{l}\text { Divi- } \\
\text { sion }\end{array}$} \\
\hline & US87 & US92 & UK88 & UK92 & US87 & US92 & UK88 & UK92 & US87 & US92 & UK88 & UK92 & \\
\hline 3811 & $\mathrm{NA}$ & NA & NA & NA & NA & $\mathrm{NA}$ & NA & NA & NA & $\mathrm{NA}$ & NA & NA & \\
\hline 3812 & NA & $\mathrm{NA}$ & NA & NA & NA & NA & NA & NA & NA & NA & NA & NA & \\
\hline 3813 & 49 & 51 & 68 & 73 & 39 & 40 & 71 & 78 & 34 & 33 & 64 & 69 & \\
\hline 3819 & $\mathrm{NA}$ & NA & $\mathrm{NA}$ & NA & $\mathrm{NA}$ & NA & NA & NA & NA & NA & NA & NA & \\
\hline 3821 & 369 & 388 & 170 & 143 & 440 & 435 & 173 & 144 & 452 & 408 & 181 & 143 & + \\
\hline 3822 & 69 & 83 & 57 & 39 & 58 & 68 & 55 & 41 & 72 & 84 & 55 & 40 & \\
\hline 3823 & 34 & 36 & 50 & 49 & 33 & 36 & 48 & 46 & 26 & 27 & 46 & 43 & \\
\hline 3824 & 70 & 75 & 117 & 121 & 70 & 74 & 127 & 137 & 64 & 64 & 130 & 159 & \\
\hline 3825 & 232 & 186 & 106 & 134 & 269 & 222 & 130 & 170 & 346 & 252 & 230 & 187 & + \\
\hline 3829 & 49 & 52 & 51 & 52 & 44 & 46 & 49 & 50 & 41 & 41 & 46 & 48 & \\
\hline 3831 & 136 & 135 & 115 & 112 & 116 & 114 & 106 & 102 & 112 & 113 & 95 & 94 & \\
\hline 3832 & 159 & 150 & 171 & 158 & 148 & 149 & 168 & 152 & 155 & 168 & 175 & 156 & + \\
\hline 3833 & 235 & 237 & 195 & 185 & 170 & 162 & 160 & 144 & 227 & 224 & 175 & 149 & + \\
\hline 3839 & 123 & 133 & 84 & 74 & 102 & 111 & 73 & 64 & 115 & 118 & 74 & 65 & \\
\hline 3841 & 97 & 93 & 111 & 105 & 84 & 78 & 110 & 103 & 64 & 57 & 75 & 83 & \\
\hline 3842 & 192 & 235 & 549 & 507 & 197 & 221 & 559 & 495 & 172 & 195 & 383 & 433 & + \\
\hline 3843 & 217 & 222 & 320 & 325 & 240 & 239 & 345 & 341 & 265 & 272 & 352 & 351 & + \\
\hline 3844 & 43 & 83 & 66 & 72 & 35 & 64 & 49 & 61 & 35 & 63 & 47 & 78 & \\
\hline 3845 & 699 & 639 & 65 & 829 & 885 & 800 & 1085 & 925 & 773 & 718 & 1038 & 916 & + \\
\hline 3851 & 149 & 142 & 81 & 86 & 157 & 154 & 73 & 77 & 147 & 150 & 73 & 86 & \\
\hline 3852 & 131 & 113 & 108 & 98 & 140 & 120 & 102 & 90 & 229 & 195 & 105 & 97 & \\
\hline 3853 & 84 & 76 & 43 & 27 & 56 & 50 & 34 & 25 & 62 & 56 & 26 & 27 & \\
\hline 3901 & 26 & 28 & 16 & 15 & 17 & 19 & 11 & 13 & 18 & 18 & 14 & 15 & \\
\hline 3902 & $\mathrm{NA}$ & NA & NA & NA & NA & NA & $\mathrm{NA}$ & $\mathrm{NA}$ & NA & $\mathrm{NA}$ & NA & NA & \\
\hline 3903 & $\mathrm{NA}$ & NA & NA & NA & NA & $\mathrm{NA}$ & $\mathrm{NA}$ & $\mathrm{NA}$ & $\mathrm{NA}$ & $\mathrm{NA}$ & $\mathrm{NA}$ & NA & \\
\hline 3909 & $\mathrm{NA}$ & $\mathrm{NA}$ & $\mathrm{NA}$ & NA & $\mathrm{NA}$ & $\mathrm{NA}$ & $\mathrm{NA}$ & NA & $\mathrm{NA}$ & $\mathrm{NA}$ & $\mathrm{NA}$ & NA & \\
\hline Total & 100 & 100 & 100 & 100 & 100 & 100 & 100 & 100 & 100 & 100 & 100 & 100 & \\
\hline
\end{tabular}

+: Chosen subsample of high-economies-of-scale industries. - NA: Data not available.

Source: Calculated from OECD (1993), Industrial Structure Statistics. Paris: OECD.

try. We define high-economies-of-scale industries as those with an index greater than 100 for all three ratios, in both countries and in all the years for which data was available. This rule ensures that we concentrate on the clear cases and it leads to seven high-economies-of-scale industries, denoted by $(+)$ in the last column of Table 3.

A first step to investigate the hypothesis is to perform an OLS estimation for the seven industries only. Taking averages of 1970-1987, the regression provides the following result:

$$
\frac{E^{U . S .}}{E^{U . K .}}=\underset{(0.36)}{0.79}+\underset{(0.04)}{0.25^{* *}} \frac{M^{U . S .}}{M^{U . K .}}, \quad\left(\overline{\mathrm{R}}^{2}=0.86\right) .
$$


The slope coefficient has the expected sign, is highly significant and has a greater value than the one of the 26 industries as proposed by the model. With an adjusted $\mathrm{R}^{2}$ of 0.86 , the linear regression fits the data very well. Also note that the seven high-economies-of-scale industries are scattered widely in Figure 2, which makes this result more relevant. ${ }^{23}$ In order to get a full picture, the same regressions as those shown in Table 2 for the 26 industries have also been performed for the subsample of the seven industries. In all nonpooled regressions, the slope coefficient has a higher value than the corresponding one of the 26 industries. The null hypothesis, $\beta_{1} \leq 0$, is rejected 5 times on the 1 percent and 4 times on the 5 percent level of significance. The average adjusted $R^{2}$ is about 0.65 . The results of the pooled regressions are reported in Table 4. They confirm the picture, as the slope coefficient is positive, significant (1 percent level) and greater than the one of the 26 industries in all OLS and GLS estimations as can easily be seen by comparing the results in Table 4 with those in the lower part of Table 2.

It is now investigated whether the coefficient found in the pooled estimations of the seven high-economies-of-scale industries is significantly different from the one obtained for the other industries. As we are primarily interested in the difference of the slope coefficient, the dummy variable variant of the Chow test is implemented where the dummy variable $(D)$ takes the value one for observations for the seven industries and the value zero otherwise. Thus,

$$
\frac{E_{i}^{\text {U.S. }}}{E_{i}^{\text {U.K. }}}=\beta_{0}+\alpha_{0} D+\beta_{1} \frac{M_{i}^{\text {U.S. }}}{M_{i}^{\text {U.K. }}}+\alpha_{1}\left(D \frac{M_{i}^{\text {U.S. }}}{M_{i}^{\text {U.K. }}}\right)+\varepsilon_{i} .
$$

We first perform an OLS estimation for the 26 industries, taking 18-year averages, as was done as a first step in all estimations. This provides the following result:

$$
\begin{array}{r}
\frac{E_{i}^{U . S .}}{E_{i}^{U . K .}}=\underset{(0.42)}{1.23^{*}}-\underset{(0.83)}{0.45 D}+\underset{(0.05)}{0.09} \frac{M_{i}^{U . S .}}{M_{i}^{U . K .}}+\underset{(0.09)}{0.16}\left(D \frac{M_{i}^{U . S .}}{M_{i}^{U . K .}}\right), \\
\left(\overline{\mathrm{R}}^{2}=0.48\right) .
\end{array}
$$

\footnotetext{
23 The seven high-economies-of-scale industries have the following coordinates (relative exports; relative home-market size) in Figure $2: 3821(2.0 ; 5.58), 3825(3.2 ; 8.01)$, 3832 (3.08; 7.79); 3833 (1.53; 4.03), 3842 (3.51; 11.53), 3843 (3.1; 10.05), 3845 (3.81; 12.7). The dispersion makes sure that, for example, the seven high-economies industries are not just clustered to the far right on a possible nonlinear relationship which becomes steeper with increasing difference in relative home-market size (see Figure 1).
} 
Table 4: Slope Coefficient of Seven High-Economies-of-Scale Industries: Pooled Estimations

\begin{tabular}{|c|c|c|c|c|}
\hline Periods/estimator & $\begin{array}{l}\text { Slope coeffi- } \\
\text { cient }\left(\beta_{1}\right)\end{array}$ & $\begin{array}{c}\text { t-value } \\
\text { of } \beta_{1}\end{array}$ & $R^{2}($ adj. $)$ & $\begin{array}{c}\text { No. of } \\
\text { observations }\end{array}$ \\
\hline \multicolumn{5}{|l|}{ 9-year averages } \\
\hline - OLS & $0.32^{\star *}$ & 6.20 & 0.74 & 14 \\
\hline - GLS (Auto) & $0.37^{\star *}$ & 6.05 & 0.73 & 14 \\
\hline - GLS (Auto, Het) & $0.37^{\star *}$ & 8.14 & 0.73 & 14 \\
\hline \multicolumn{5}{|l|}{ 6-year averages } \\
\hline- OLS & $0.30^{\star \star}$ & 6.62 & 0.68 & 21 \\
\hline - GLS (Auto) & $0.35^{\star *}$ & 6.29 & 0.66 & 21 \\
\hline - GLS (Auto, Het) & $0.35^{\star *}$ & 6.61 & 0.66 & 21 \\
\hline \multicolumn{5}{|l|}{3 -year averages } \\
\hline- OLS & $0.31^{\star *}$ & 8.84 & 0.65 & 40 \\
\hline - GLS (Auto) & $0.30^{\star *}$ & 6.03 & 0.46 & 40 \\
\hline - GLS (Auto, Het) & $0.30^{\star *}$ & 5.03 & 0.46 & 40 \\
\hline \multicolumn{5}{|l|}{ 1-year averages } \\
\hline - OLS & $0.31^{* *}$ & 13.57 & 0.59 & 124 \\
\hline - GLS (Auto) & $0.24^{\star *}$ & 6.63 & 0.26 & 124 \\
\hline - GLS (Auto, Het) & $0.24^{* *}$ & 5.26 & 0.26 & 124 \\
\hline \multicolumn{5}{|c|}{$\begin{array}{l}* \text { significant at the } 1 \text { percent level. }-^{*} \text { significant at the } 5 \text { percent level. - GLS (Auto) } \\
=\text { OLS in transformed data, corrected for first-order autocorrelation. - GLS (Auto, Het) } \\
=\text { OLS in transformed data, corrected for first-order autocorrelation and applying the } \\
\text { White estimator for an unknown form of heteroskedasticity. }\end{array}$} \\
\hline
\end{tabular}

The slope coefficients have the expected sign, but are not significant. In order to exploit the full information in the data set we perform pooled estimations of (15). The results are reported in Table 5. The first two columns show that the slope coefficients $\left(\beta_{1}\right.$ and $\left.\alpha_{1}\right)$ become significant. We can then perform an F-test on the null hypothesis, $\alpha_{1}=0$, i.e., we test whether the slope coefficient of the seven high-economies-of-scale industries is significantly different from that of the other industries. The third and fourth column of Table 5 presents the results and also distinguishes between a Chow test that includes all 26 industries (third column, "A") and one which excludes those six industries for which data regarding economies of scale where not available (fourth column, " $\mathrm{B}$ "). The null hypothesis is rejected in all F-tests of the pooled estimations at the 1 percent level of significance. As can be seen from Table 5, the F-value changes quite a bit if the data is corrected for autocorrelated [GLS (Auto)] and heteroskedastic [GLS (Auto, Het)] error terms. But the quality of the result remains unaffected. 
Table 5: Chow Test for Pooled Estimations: Slope Coefficients and Hypothesis Test $\left(H_{0}\right.$ : slope coefficient of 7 industries and of other industries are equal

\begin{tabular}{|c|c|c|c|c|c|c|}
\hline Periods/estimator & $\begin{array}{c}\text { Slope coe } \\
\left(\beta_{1}\right) \mathrm{A}\end{array}$ & $\begin{array}{l}\text { efficients } \\
\qquad\left(\alpha_{1}\right)\end{array}$ & $\begin{array}{c}\text { F-value of } \alpha_{1} \\
\text { A }\end{array}$ & $\begin{array}{c}\text { F-value of } \alpha_{1} \\
\text { B }\end{array}$ & $\begin{array}{c}\mathrm{R}^{2}(\mathrm{adj} .) \\
A\end{array}$ & $\begin{array}{c}\text { No. of obs. } \\
\text { A }\end{array}$ \\
\hline \multicolumn{7}{|l|}{ 9-year averages } \\
\hline - OLS & $0.09^{*}$ & $0.24^{* *}$ & $\mathrm{~F}_{48}^{1}=11.8^{* *}$ & $\mathrm{~F}^{1}{ }_{36}=14.7^{\star *}$ & 0.55 & 52 \\
\hline - GLS (Auto) & $0.10^{*}$ & $0.26^{\star *}$ & $\mathrm{~F}^{1{ }^{10}}=13.1^{\star \star}$ & $\mathrm{F}_{36}^{10}=15.2^{* *}$ & 0.55 & 52 \\
\hline - GLS (Auto, Het) & $0.10^{* *}$ & $0.26^{\star *}$ & $\mathrm{~F}_{48}^{10}=20.2^{* \star}$ & $\mathrm{F}_{36}^{1}=27.9^{* *}$ & 0.55 & 52 \\
\hline \multicolumn{7}{|l|}{ 6-year averages } \\
\hline - OLS & $0.08^{*}$ & $0.22^{* *}$ & $F^{1}{ }_{74}=16.1^{* *}$ & $\mathrm{~F}_{56}^{1}=19.7^{* *}$ & 0.53 & 78 \\
\hline - GLS (Auto) & $0.09^{*}$ & $0.25^{* *}$ & $\mathrm{~F}_{74}^{\mathrm{l}_{74}^{\prime 4}}=18.9^{* *}$ & $\mathrm{~F}_{56}^{10}=19.7^{* *}$ & 0.53 & 78 \\
\hline - GLS (Auto, Het) & $0.09^{* *}$ & $0.25^{* *}$ & $F^{1}{ }_{74}=16.2^{* *}$ & $\mathrm{~F}_{56}^{\mathrm{l}^{*}}=21.4^{* *}$ & 0.53 & 78 \\
\hline \multicolumn{7}{|l|}{ 3-year averages } \\
\hline - OLS & $0.08^{* *}$ & $0.23^{\star *}$ & $\mathrm{~F}_{152}^{1}=30.8^{* *}$ & $F_{116}^{1}=37.4^{\star *}$ & 0.51 & 156 \\
\hline - GLS (Auto) & $0.10^{\star \star}$ & $0.20^{* *}$ & $\mathrm{~F}_{152}^{1}=17.0^{* *}$ & $\mathrm{~F}_{116}^{1}=16.7^{\star *}$ & 0.36 & 156 \\
\hline - GLS (Auto, Het) & $0.10^{* *}$ & $0.19^{* *}$ & $\mathrm{~F}_{152}^{1}=9.3^{* *}$ & $\mathrm{~F}_{116}^{1}=12.2^{* *}$ & 0.36 & 156 \\
\hline \multicolumn{7}{|l|}{ 1-year averages } \\
\hline - OLS & $0.08^{* *}$ & $0.23^{* *}$ & $F_{464}^{1}=83.7^{* *}$ & $\mathrm{~F}_{356}^{1}=95.9^{* *}$ & 0.49 & 468 \\
\hline - GLS (Auto) & $0.09^{* *}$ & $0.15^{\text {** }}$ & $\mathrm{F}_{464}^{1^{404}}=23.9^{* *}$ & $\mathrm{~F}_{356}^{\mathrm{l}_{356}}=21.4^{* *}$ & 0.23 & 468 \\
\hline - GLS (Auto, Het) & $0.09^{* *}$ & $0.15^{* *}$ & $\mathrm{~F}_{464}^{\mathrm{l}^{404}}=9.3^{* *}$ & $\mathrm{~F}_{356}^{\mathrm{l}^{300}}=10.4^{* *}$ & 0.23 & 468 \\
\hline
\end{tabular}

A: With all 26 industries. - B: With 20 industries (26 industries excluding those for which data are not available (see Table 3$)$ ). - ** significant at the 1 percent level. - ${ }^{*}$ significant at the 5 percent level. GLS (Auto) = OLS in transformed data, corrected for first-order autocorrelation. - GLS (Auto, Het) = OLS in transformed data, corrected for first-order autocorrelation and applying the White estimator for an unknown form of heteroskedasticity.

RESULT 2: There is clear support of the second hypothesis that the relationship between relative home-market size and relative exports is stronger in those industries with large economies of scale.

This result is based on the higher value of the slope coefficient and the improved goodness of fit for the seven high-economies-of-scale industries in all pooled and nonpooled regressions. The performed Chow test confirms this result with a strong rejection of the null hypothesis in all pooled regressions that the slope coefficients are identical for the lowand high-economies-of-scale industries.

\section{Conclusions}

This paper analyzes the question of whether countries might export more of those goods for which they have a large home market. To focus on home-market effects, I concentrate on a simple two-country, many- 
good general-equilibrium model that allows for differences in relative and absolute home-market size in different industries among the two countries. Based on this model, it is possible to analyze how differences in industry-specific home-market sizes affect the pattern of trade and how a change in the elasticity of substitution as an inverse index of scale economies affects this relationship. This leads to the hypotheses that (1) each country tends to export relatively more of those goods for which its home market is relatively larger and that (2) this relationship becomes stronger if industries are characterized by a greater degree of economies of scale. The latter is measured by a larger average firm size in an industry as a proxy for greater fixed costs. Confronted with a data set of British and American home-market sizes and exports for 26 industries over the period 1970-1987, both hypotheses are supported, i.e., they cannot be rejected.

Overall, these empirical results support Linder's (1961) suggestion that domestic demand may be an important determinant of a country's exports for certain industries. The results are complementary to recent findings by a number of papers mentioned in the introduction to this paper. The analysis indicates that increasing returns to scale seem to be crucial to the existence of home-market effects as, in fact, predicted by both the traditional and the new trade theories. In addition to this literature, the paper suggests that the size of home-market effects may even differ within a group of industries with different degrees of economies of scale; high-economies-of-scale industries may benefit more from a larger home market than other industries. Thus, the analysis provides evidence for models where home-market effects do depend on fixed costs or average firm size.

There are, however, limitations to the straightforward analysis in this paper which indicate directions for future research. First, the model has a limited capability to assess the impact of a change in fixed costs or, more generally, in the degree of scale economies on home-market effects. A more satisfactory, but also more complex, approach would be based on a model with an endogenous elasticity of substitution that depends on the equilibrium number of firms in a market. A promising model in this regard is Ottaviano et al. (2002). Second, the empirical analysis is restricted to two countries, a limited number of industries, and a rather indirect way of controlling for any differences among countries by selecting only those industries with a high degree of intraindustry trade. A more comprehensive analysis would enlarge the choice of industries 
and explicitly take into account, and control for, differences such as factor endowment or technology. Third, the distinction between low- and high-economies-of-scale industries based on average firm size as a proxy for high fixed costs remains relatively crude and could, if data permitted, be extended by more sophisticated ways of assessing the effects of this important industry characteristic.

Thus, the mentioned analogy between the demand-driven intraindustry trade model proposed in this paper and the classical Ricardian theory of international trade seems also to apply to the two models' empirical tests with all their strengths and weaknesses.

\section{Appendix}

The relative number of varieties of good $i$ produced in the home $\left(n_{i}\right)$ and foreign country $\left(n_{i}^{*}\right)$ can be derived by calculating each country's demand for home and foreign produced varieties from equations (2) and (5), taking into account the optimal pricing rule and, therefore, the optimal quantity produced in equilibrium from (3) (see Weder 1995: 344 for the two-good case). Thus,

$$
n_{i} / n_{i}^{*}=\left[\left(s_{i} / s_{i}^{*}\right)-q B\right] /\left[B-q^{*}\left(s_{i} / s_{i}^{*}\right)\right],
$$

where

$$
\begin{aligned}
B & =\left(L^{*} / L\right)\left[1-q^{*}\left(w^{*} / w\right)\right] /\left[1-q\left(w / w^{*}\right)\right] \\
q & =\left(w / w^{*}\right)^{\sigma-1} t^{1-\sigma} \\
q^{*} & =\left(w^{*} / w\right)^{\sigma-1} t^{1-\sigma} .
\end{aligned}
$$

The equilibrium relative wage $\left(w / w^{*}\right)$ can be found by requiring that there is balanced trade between the two countries over all $G$ goods:

$$
\begin{aligned}
& T_{i}=X_{i}-X_{i}^{*}=\left[n_{i} q^{*} /\left(n_{i}^{*}+n_{i} q^{*}\right)\right] s_{i}^{*} w^{*} L^{*}-\left[n_{i}^{*} q /\left(n_{i}+n_{i}^{*} q\right)\right] s_{i} w L, \\
& \sum_{i=1}^{G} T_{i}=\sum_{i=1}^{G}\left[s_{i}^{*} /\left(n_{i}^{*}+n_{i} q^{*}\right)\right]\left[n_{i} q^{*} w^{*} L^{*}-n_{i}^{*} q B w L\right]=0
\end{aligned}
$$

Substituting (A1) in (A2) and taking into account that the sum of the expenditure shares equals one, the relationship between relative wages and relative country sizes as shown in (6) can be found:

$$
L / L^{*}=\left[\left(w / w^{*}\right)^{\sigma}-t^{1-\sigma}\right] /\left[\left(w / w^{*}\right)^{1-\sigma}-\left(w / w^{*}\right) t^{1-\sigma}\right] .
$$

Relative exports of the two countries for each good $i$ are determined by the ratio of the foreign country's demand for home's varieties of good $i\left(X_{i}\right)$ and 
the home country's demand for foreign varieties of good $i\left(X_{i}^{*}\right)$ :

$$
X_{i} / X_{i}^{*}=\frac{n_{i} q^{*} /\left(n_{i}^{*}+n_{i} q^{*}\right)}{n_{i}^{*} q /\left(n_{i}+n_{i}^{*} q\right)} \frac{s_{i}^{*} w^{*} L^{*}}{s_{i} w L} .
$$

Substituting (A1) and (A3) in (A4) yields the following relationship between relative exports and relative expenditures as shown in (7). Note that $s_{i} L=M_{i}$ and $s_{i}^{*} L^{*}=M_{i}^{*}$ :

$$
\frac{X_{i}}{X_{i}^{*}}=\frac{\left(s_{i} L / s_{i}^{*} L^{*}\right)\left[1-q\left(w / w^{*}\right)\right]+\left[q q^{*}\left(w^{*} / w\right)-q\right]}{\left(L / L^{*}\right)\left[1-q^{*}\left(w^{*} / w\right)\right]+\left(s_{i} L / s_{i}^{*} L^{*}\right)\left[q q^{*}-q\left(w / w^{*}\right)\right]} .
$$

\section{References}

Balassa, B. (1963). An Empirical Demonstration of Classical Comparative Cost Theory. Review of Economics and Statistics 45 (3): 231-238.

Basevi, G. (1970). Domestic Demand and Ability to Export. Journal of Political Economy 78 (2): 330-337.

Bhagwati, J. (1964). The Pure Theory of International Trade: A Survey. Economic Journal 74 (March): 1-84.

Bhagwati, J. N. (1982). Shifting Comparative Advantage, Protectionist Demands, and Policy Response. In J. N. Bhagwati (ed.), Import Competition and Response. Chicago: University of Chicago Press.

Brülhart, M., and F. Trionfetti (2001). Industrial Specialisation and Public Procurement: Theory and Empirical Evidence. Journal of Economic Integration 16 (1): 106-127.

Brïlhart, M., and F. Trionfetti (2002a). Public Expenditure and International Specialisation. Mimeo. University of Lausanne, January.

Brülhart, M., and F. Trionfetti (2002b). A Test of Trade Theories When Expenditure Is Home Biased. Mimeo. University of Lausanne, March.

Davis, D. R. (1995). Intraindustry Trade: A Heckscher-Ohlin-Ricardo Approach. Journal of International Economics 39 (3/4): 201-226.

Davis, D. R. (1998). The Home Market, Trade and Industrial Structure. American Economic Review 88 (5): 1264-1276.

Davis, D. R., and D. E. Weinstein (1996). Does Economic Geography Matter for International Specialization? NBER Working Paper 5706. National Bureau of Economic Research, Cambridge, Mass.

Davis, D. R., and D. E. Weinstein (1998). Market Access, Economic Geography and Comparative Advantage: An Empirical Test. Journal of International Economics 59 (1): 1-23.

Davis, D. R., and D. E. Weinstein (1999). Economic Geography and Regional Production Structure: An Empirical Investigation. European Economic Review 43 (2): 379-407. 
Deardorff, A. V. (1984). Testing Trade Theories and Predicting Trade Flows. In R. W. Jones and P. J. Neary (eds.), Handbook of International Economics. Vol. II. Amsterdam: Elsevier.

Dinopoulos, E. (1988). A Formalization of the 'Biological' Model of Trade in Similar Products. Journal of International Economics 25 (1/2): 95-110.

Ethier, W. J. (1982). National and International Returns to Scale in the Modern Theory of International Trade. American Economic Review 72 (3): 389 405.

Fagerberg, J. (1995). User-Producer Interaction, Learning and Comparative Advantage. Cambridge Journal of Economics 19 (1): 243-256.

Feenstra, R. C. (1982). Product Creation and Trade Patterns: A Theoretical Note on the 'Biological' Model of Trade in Similar Products. In J. N. Bhagwati (ed.), Import Competition and Response. Chicago: University of Chicago Press.

Feenstra, R. C., J. A. Markusen, and A. K. Rose (1998). Understanding the Home Market Effect and the Gravity Equation: The Role of Differentiating Goods. NBER Working Paper 6804. National Bureau of Economic Research, Cambridge, Mass.

Frenkel, J. A. (1971). On Domestic Demand and Ability to Export. Journal of Political Economy 79 (3): 668-674.

Grubel, H. G., and P. J. Lloyd (1975). Intra-Industry Trade. The Theory and Measurement of International Trade in Differentiated Products. New York: John Wiley \& Sons.

Harrigan, J. (1994). Scale Economies and the Volume of Trade. The Review of Economics and Statistics 76 (2): 321-328.

Harris, R. (1984). Applied General Equilibrium Analysis of Small Open Economies with Scale Economies and Imperfect Competition. American Economic Review 74 (5): 1016-1032.

Head, K., and J. Ries (2001). Increasing Returns Versus National Product Differentiation as an Explanation for the Pattern of U.S.-Canada Trade. American Economic Review 91 (4): 858-876.

Head, K., T. Mayer, and J. Ries (2002). On the Pervasiveness of Home Market Effects. Economica 69 (August): 371-390.

Hsu, R. C. (1972). Changing Domestic Demand and Ability to Export. Journal of Political Economy 80 (1): 198-202.

Hummels, D., and J. Levinsohn (1995). Monopolistic Competition and International Trade: Reconsidering the Evidence. Quarterly Journal of Economics 110 (3): 799-836.

Jones, R. W. (1956). Factor Proportions and the Heckscher-Ohlin Theorem. Review of Economic Studies 14 (63): 1-10.

Jones, R. W., and P. J. Neary (1984). The Positive Theory of International Trade. In R. W. Jones and P. J. Neary (eds.), Handbook of International Economics. Vol. II. Amsterdam: Elsevier. 
Krugman, P. R. (1979). Increasing Returns, Monopolistic Competition, and International Trade. Journal of International Economics 9 (4): 469-479.

Krugman, P. R. (1980). Scale Economies, Product Differentiation, and the Pattern of Trade. American Economic Review 70 (5): 950-959.

Leamer, E. E., and J. Levinsohn (1995). International Trade Theory: The Evidence. In G. M. Grossman and K. Rogoff (eds.), Handbook of International Economics. Vol. III. Amsterdam: Elsevier.

Linder, S. B. (1961). An Essay on Trade and Transformation. New York: John Wiley \& Sons.

Loertscher, R., and F. Wolter (1980). Determinants of Intra-Industry Trade: among Countries and across Industries. Weltwirtschaftiches Archiv/Review of World Economics 116 (2): 280-293.

Lundbäck, E., and J. Torstensson (1998). Demand, Comparative Advantage and Economic Geography in International Trade: Evidence from the OECD. Weltwirtschaftliches Archiv/Review of World Economics 134 (2): 230-249.

MacDougall, G. D. A. (1951). British and American Exports: A Study Suggested by the Theory of Comparative Costs. Part I. Economic Journal 61 (December): 697-724.

Mercenier, J., and N. Schmitt (1996). On Sunk Costs and Trade Liberalization in Applied General Equilibrium. International Economic Review 37 (3): 553-571.

OECD (1993). Industrial Structure Statistics. Paris: OECD.

Ottaviano, G., T. Tabuchi, and J.-F. Thisse (2002). Agglomeration and Trade Revisited. International Economic Review 43 (2): 409-435.

Stern, R. M. (1962). British and American Productivity and Comparative Costs in International Trade. Oxford Economic Papers 14 (3): 275-296.

Trionfetti, F. (200la). Public Procurement, Market Integration, and Income Inequalities. Review of International Economics 9 (1): 29-41.

Trionfetti, F. (2001b). Using Home-Biased Demand to Test Trade Theories. Weltwirtschaftliches Archiv/Review of World Economics 137 (3): 404-426.

Vernon, R. (1966). International Investment and International Trade in the Product Cycle. Quarterly Journal of Economics 80 (2): 190-207.

Weder, R. (1995). Linking Absolute and Comparative Advantage to IntraIndustry Trade Theory. Review of International Economics 3 (3): 342-354.

Weder, R. (1996). How Domestic Demand Shapes the Pattern of Trade. World Economy 19 (3): 273-286. 